\title{
Anti-corruption Agencies - Silver Bullet Against Corrupion or Fifth Wheel to a Coach? Analysis from the Perspective of the Constructivist Theory of Social Problems
}

\begin{abstract}
Constructivism is the most dynamically evolving concept in the sociology of social problems ${ }^{1}$. The research projects based on this paradigm, especially those dedicated to corruption, provide valuable insights and opportunities to formulate conclusions on the nature of this phenomenon, which would be difficult to derive from other theoretical traditions ${ }^{2}$. The main purpose of this paper is to show how a constructivist approach might be used to better understand the nature of modern corruption, and why one of the most popular solutions nowadays, anti-corruption agencies (ACAs), so often fail. The author's main argument is that one of the most important reasons why the ACAs fail is strongly related to how a social problem of corruption is constructed.
\end{abstract}

Keywords: social problems, constructivism, corruption, anti-corruption agencies

1 E. Rubington, M.S. Weinberg, The Study of Social Problems. Seven Perspectives (Sixth Edition), Oxford University Press, New York 2003; S. Woolgar, D. Pawluch, How Shall We Move Beyond Constructivism, "Social Problems" 1985, Vol. 3, No. 2, p. 159-162; J. Best, Constructionism in Context, in: J. Best (Ed.), Images of Issues: Typifying Contemporary Social Problems, New York 1995.

2 V. Pavarala, Interpreting Corruption. Elite Perspectives in India, Sage Publications, New Delhi 1996; I. Krastev, When "Should" Does Not Imply "Can" The Making of the Washington Consensus on Corruption, in: W. Lepenies (Ed.), Entangled Histories and Negotiated Universals: Centers and Peripheries in a Changing World, Campus Verlag, Frankfurt 2000: G. Makowski, Korupcja jako problem społeczny, Trio, Warsaw 2008. 


\section{Agencje antykorupcyjne - cudowne panaceum przeciwko korupcji czy piąte koło u wozu? Analiza z perspektywy konstruktywistycznej teorii problemów społecznych}

\section{Streszczenie}

Konstruktywizm to najbardziej dynamicznie rozwijająca się koncepcja w socjologii problemów społecznych ${ }^{3}$. Projekty badawcze oparte na tym paradygmacie, zwłaszcza te poświęcone korupcji, dostarczają cennych informacji i umożliwiają formułowanie wniosków na temat natury tego zjawiska, co byłoby trudne do osiągnięcia na podstawie innych teoretycznych tradycji ${ }^{4}$. Głównym celem tego artykułu jest pokazanie, w jaki sposób konstruktywistyczne podejście może być zastosowane, aby lepiej zrozumieć naturę współczesnej korupcji i dlaczego jedno z najbardziej popularnych rozwiązań w dzisiejszych czasach, agencje antykorupcyjne (ACAS), tak często zawodzą. Według autora jeden $\mathrm{z}$ najważniejszych powodów, dlaczego ACAS nie są skuteczne, jest silnie związany z tym jak problem społeczny korupcji jest skonstruowany.

Słowa kluczowe: problemy społeczne, konstruktywizm, korupcja, agencje antykorupcyjne

\section{Constructing and converting social problems}

One of the most recent and interesting variants of the constructivist approach is Jamrozik's theory of the residualist conversion of social problems. Within his concept a social problem is a set of circumstances, attitudes, processes and structures, perceived and defined by people as threatening to their values, objectives, hierarchies, or moral standards or to institutions considered by the society or given groups to be essential to maintain social stability ${ }^{5}$. Those who signalize problems and demand changes in constructivist theories are called claims-makers.

3 E. Rubington, M.S. Weinberg, The Study of Social Problems. Seven Perspectives (Sixth Edition), Oxford University Press, New York 2003; S. Woolgar, D. Pawluch, How Shall We Move Beyond Constructivism, "Social Problems" 1985, Vol. 3, No. 2, s. 159-162; J. Best, Constructionism in Context, w: J. Best (Ed.), Images of Issues: Typifying Contemporary Social Problems, New York 1995.

4 V. Pavarala, Interpreting Corruption. Elite Perspectives in India, Sage Publications, New Delhi 1996; I. Krastev, When "Should" Does Not Imply "Can" The Making of the Washington Consensus on Corruption, w: W. Lepenies (Ed.), Entangled Histories and Negotiated Universals: Centers and Peripheries in a Changing World, Campus Verlag, Frankfurt 2000: G. Makowski, Korupcja jako problem społeczny, Trio, Warszawa 2008.

5 A. Jamrozik, L. Nocella, The Sociology of Social Problems. Theoretical Perspectives and Methods of Intervention, Cambridge University Press, Cambridge 1998; G. Makowski, op.cit. 
Social problems are phenomena in which a paradox is always embedded - on the one hand, they are a real or putative source of threat to social norms and values, on the other hand they occur as a result of efforts to realize the standards, values and goals that are based on those values. Hence, Jamrozik also defines social problems as the negative residues of efforts of society to achieve its objectives arising from the particular normative system. This also means that social problems are structural in their nature; they are built into concrete social arrangements and are reproduced by them.

Taking this into account an important conclusion is that the key to solving any social problem always lies in the hands of those who can make a systemic change possible - the authorities - since they are the guardians of the normative order, and their mission is to secure public interest and shape public policies. If social problems are structural, then they can be resolved only by changing the system or at least some significant part of it. This always means redefinition of some fundamental social values and societal goals.

Construction and further conversion of social problems depend on many factors. One of the most important is so called the "organizational ownership" of the problem 6 . In short, this is the ability to label certain phenomena (putative or real) as problems and undertake actions against them. Ownership is the ability to manipulate the meaning, definition of the problem and to manage it, but it is also a set of obligations and responsibilities for formulation of policy towards the problem.

Owners and forms of ownership of social problems change over time. There are at least three types of actors competing for organizational ownership of social problems. In the first group there are all those (groups, organizations, social movements or individuals) who make claims; they initiate the process of constructing social problems, they name given circumstances or situations (real or putative) as problematic. They bring the problems to the public arena (usually through all kinds of media) and demand a reaction from the authorities. "Moral entrepreneurs" and "do-gooders" usually have a particularly strong sense of ownership, and are strongly motivated by some fundamental (moral or religious) values, interests or beliefs. Consequently, they are the first to own the problem.

Another category of actors seeking organizational ownership of the problems are the authorities themselves; they decide to legitimize claims and naturally want to take over the ownership of the problem. Sometimes authorities even take the role of claims-makers and own the problems from the very beginning ${ }^{7}$. By generating

6 J.R. Gusfield, Constructing the Ownership of Social Problems: Fun and Profit in the Welfare State, "Social Problems" 1989, Vol. 36, No. 5, 431-441.

7 J.W. Schneider, Social Problems Theory: The Constructionist View, "Annual Reviews" 1985, No. 11, 209-229; Girard R., Kozioł ofiarny, Wydawnictwo Łódzkie, Łódź 1991. 
social problems they want to show how effective they are in protecting society and the public interest ${ }^{8}$. In any case, as public policy makers they are naturally interested in such a reformulation of a social problem that it will not undermine their competences as actors responsible for securing the public interest.

Finally, the third major category of actors aspiring to own social problems are agencies and institutions (the referral agencies or helping professions) formed by the authorities to implement public policies, e.g. labor offices, social welfare institutions and law enforcement bodies. Anti-corruption agencies, to which the second part of this paper is devoted, also belong to this category ${ }^{9}$. These actors are active at an operational level. They create a source of practical, specialized knowledge about the problem which they are dealing with, tending at the same time to hide this knowledge, because it gives them autonomy and a stronger position towards other competitors for ownership of the problem. The functioning of such institutions is characterized by a symbiotic relationship with the problem - helping professions work best when the problem is personalized, when they have their own "problem population". It is then easy to "feed" the problem by adjusting individual cases of "deviation" or "pathology" to the operational definition of the problem, which such institutions use for their daily purposes, to maintain the problem. Often, the existence of such groups, in addition to being a specialized knowledge resource, becomes the sine qua non condition for the existence of a referral agency or helping profession. When such institutions are the owners, they often become more interested in maintaining the problem at a reasonable scale - big enough to ensure that their existence makes sense. This often means attempting to adjust and extend the definition of the problem, so it covers a wider range of individuals or behaviors that should be treated as problematic.

\section{Corruption as social problem}

From the constructivist perspective the precise definition of corruption is not as important as specific features of this phenomenon ${ }^{10}$. One such feature is that corruption is undeniably related to the functioning of public authorities. Corruption is always a question of power and, in particular, a question of the public authorities ${ }^{11}$.

\footnotetext{
8 J.W. Schneider, op.cit.

9 J.R. Gusfield, Constructing the Ownership of Social Problems: Fun and Profit in the Welfare State, "Social Problems" 1989, Vol. 36, No. 5, 431-441.

10 G. Makowski, op.cit; V. Pavrala, op.cit.

11 J. Kurczewski, Czy możliwa jest socjologia korupcji?, in: J. Kurczewski, B. Łaciak (Ed.), Korupcja $w \dot{z} y c i u$ społecznym, ISP, Warsaw 2000.
} 
This feature is also the reason why, in most cases, the bottom-up process attempts to construct corruption as a social problem are unsuccessful. Recognizing corruption as a social problem and legitimizing it officially as such, like no other phenomenon, calls into question the position, competences, and eventually the ability of authorities to preserve the socio-political status quo. This is why authorities naturally are unwilling to recognize this threat. Therefore, the process of constructing corruption as a social problem has rather a top-down than bottom-up character - if the authorities discover that there is some use for this - e.g. to discredit political opponents.

There is another possibility for constructing corruption as a social problem. Often, whether it becomes a social problem in a particular country or not is determined by international pressure ${ }^{12}$. Institutions such as the European Union, OECD, UN, World Bank or influential international non-governmental organizations such as the Transparency International may act as really powerful claim-makers. They are capable of efficiently producing public discourse on corruption motivating the public authorities (governments) to take action, forcing them to legitimize corruption as a social problem. This fact is of great importance for the construction and conversion processes and, as we will see later, for the anti-corruption agencies. In such situations organizational ownership of the social problem of corruption usually remains in the hands of international organizations. They keep the ownership even when corruption becomes a problem legitimized by national governments. Using international conventions and programs these organizations often have the final word about definitions of corruption and actions that should be undertaken in particular countries ${ }^{13}$.

This creates a specific situation in which governments are forced to take responsibility for creating anti-corruption policies, but without having ownership of the problem. Under pressure from international organizations, they cannot contest the threat anymore and must legitimize the social problem of corruption, develop anti-corruption policies and implement them. At the same time, international organizations seldom demand real systemic changes (e.g. reform of political party financing, administrative changes or deeper fundamental reformulation of the constitutional order in a country) - simply because they don't have the mandate to interfere with

12 I. Krastev, A. Stoyanov, Prime Minister's Dilemma: Do Non-Corrupt Governments, “Working Paper Collegium", Budapest 2003, www.colbud.hu/honesty-trust/krastev/pub03.doc. Accessed 11 August 2012; A. Sík, The Bad, the Worse and the Worst: Guesstimating the Level of Corruption, in: A. Sajó, S. Kotkin (Ed.), Political Corruption in Transition: A Skeptic's Handbook, CEU Press, New York 2002, p. 91-114.

13 I. Krastev, When "Should" Does Not Imply "Can" The Making of the Washington Consensus on Corruption, Fribourg Institute of Federalism, Fribourg 2003; G. Makowski, op.cit., p. 279-288; I. Krastev, A. Stoyanov, op.cit. 
national policies ${ }^{14}$ (Polzer, 2001). Therefore the chances of solving the problem of corruption by some systemic change is rather small.

Also personalization (what in brief means identifying the source of the problem in concrete groups or individuals ${ }^{15}$ of the social problem of corruption is almost impossible under such conditions, what would not be a solution of course, but from the point of view of governments this could make corruption more manageable. The authorities cannot easily determine a problem population - they cannot point to who a "convenient enemy" or "scapegoat" is. It is difficult because these authorities (political parties, government and public administration) are the ones who are usually blamed for corruption by society. In such circumstances, the authorities try to find and blame some particular socio-professional group (e.g. low level officials or public health employees). In such a situation they are able to maintain the status quo only by diffusing the social problem of corruption. Putting the responsibility for corruption on everyone means presenting it as a problem of the whole society, as a cultural problem, as a phenomenon deeply rooted in the national history, etc. Only conversion by diffusion gives the authorities an opportunity to distance themselves from the problem and define their role as the only body able to find good solutions.

There is one important constraint, however. Diffused corruption is difficult to convert into a technical issue, as there is no specific "problem population" to blame. Conversion in this form usually ends at the "administrative level", where only some general strategies are implemented; sometimes institutions responsible for solving a problem are reorganized; or educational activities are undertaken. When corruption is diffused, an attempt to go deeper, to the operational level, and deal with it by creating specific helping professions, e.g. special anti-corruption agencies, might not be very effective. The main difficulty is to formulate the mission and mandate of such institutions and assign to them proper resources (financial, human and technical).

Nevertheless, governments (especially in developing countries) under international pressure decide to establish such "anti-corruption helping professions". An overview of such institutions suggests that in most cases they are rather dysfunctional. The main hypothesis of this article is that their defects are related to the diffused nature of modern corruption. Before arguments for this standpoint will be presented and some illustrations from available research, it will be useful to define what an anti-corruption agency is.

14 T. Polzer, Corruption: Deconstructing the World Bank Discourse, LSE Working Papers 2001, http:// www2.lse.ac.uk/internationalDevelopment/pdf/WP18.pdf. Accessed 11 August 2012.

${ }^{15}$ See: G. Makowski, op.cit, p. 95-96. 


\section{Anti-corruption agency - definition and brief history}

Within the ANCORAGE-NET project ${ }^{16}$, devoted to the anti-corruption agencies, several pioneering studies have already been conducted. Researchers involved in this initiative propose a definition of the ACAs, according to which such institutions are "[...] public bodies of a durable nature, with a specific mission to fight corruption and reducing the opportunity structures propitious for its occurrence in society through preventive and/or repressive measures. Independently of their format and powers $[\ldots]^{\prime \prime} 17$.

One of the first OECD reports on ACAs defined them as " [...] permanent agencies whose primary function is to provide centralized leadership in one or more of the core areas of anti-corruption activity - including policy, analysis and technical assistance in prevention, public outreach and information, monitoring, investigation, and prosecution" ${ }^{18}$ Unlike the ANCORAGE-NET researchers, the OECD definition immediately points out some specific features of the ACAs. Following the OECD definition, one may distinguish three major types of a central anti-corruption agency (Meagher, 2007):

- Multi-purpose agencies - combining several functions - policy making, research, educational, also law enforcement (e.g. the Singaporean Corrupt Practices Investigation Bureau (CPIB), the Independent Commission Against Corruption (ICAC) in Hong Kong or New South Wales in Australia).

- Law enforcement agencies - these are basically law enforcement bodies or secret services. Such institutions exist, for example, in Norway, Spain and Belgium. Close to this type of the ACA is also the Polish Central Anti-corruption Bureau.

- Preventive, policy development and co-ordination institutions - the ACAs with a loose structure and generally defined purposes - commissions, councils or other collective bodies composed of representatives of other institutions - police, prosecution and other law enforcement agencies, etc. (e.g. the ACAs operating in France, Slovenia or in the USA).

The special groups of prosecutors and police investigative teams which operated in New York in the seventies of the nineteenth century are considered to be the

16 http://ancorage-net.org/

17 L. de Sousa, Anti-corruption Agencies: Between Empowerment and Irrelevance. Robert Schuman Centre for Advanced Studies Working Papers 2009, http://ancorage-net.org/content/documents/anti-corruption\%20agencies\%20between\%20empowerment\%20and\%20irrelevance.pdf. Accessed 11 August 2012.

18 P. Meagher, Anti-Corruption Agencies: A Review of Experience, University of Maryland: Center for Institutional Reform and the Informal Sector, 2004, p. 3. 
ancestors of modern anti-corruption agencies ${ }^{19}$. Around the same time as in the U.S. similar initiatives were undertaken in some Asian countries.

In 1937, Singapore adopted special anti-corruption legislation, Prevention of Corruption Ordinance, establishing a permanent police unit dedicated to fighting corruption $^{20}$. In 1952 this unit was transformed to the Corrupt Practices Investigation Bureau (CPIB). The CPIB became famous only after the reforms which this institution went through in the following twenty years ${ }^{21}$. The Independent Commission Against Corruption (ICAC) of Hong Kong, established in 1974, is also among the oldest central anti-corruption bodies. Nowadays the ICAC remains the largest and best-funded anti-corruption agency in the world. It was also recognized as the best model to follow for countries such as Brunei, Uganda and Zambia (although it is worth noting that operating of the ICAC in most cases did not bring the expected results, for reasons that will be explained later).

Portugal was the first European country to establish an anti-corruption agency - Alta Autoridade Contra a Corrupção, formed on the model of Singapore's CPIB. In 1988, based on the experience of Hong Kong's ICAC, a similar commission was established in New South Wales (Australia).

In the seventies and eighties of the twentieth century most of the ACAs were established as the best remedy to the institutional weaknesses of postcolonial states ${ }^{22}$. Countries which received independence inherited from their masters a political system and administrative structures which did not fit the local culture and society. Therefore these new states were more exposed to corruption. The response to this threat was, among others, the establishment of special anti-corruption bodies.

The second wave of popularity of the ACAs was the beginning of the nineties. During this time the United Nations intensified its anti-corruption efforts. The UN Development Program started implementing projects aimed at strengthening public administration in developing countries ${ }^{23}$. With the expansion of the free market economy, many authoritarian regimes decided to implement reforms, hoping to attract

19 P. Meagher, Anti-corruption Agencies: Rhetoric Versus Reality, "Journal of Policy Reform” 2005, Vol. 8, No. 1, p. 70.

${ }^{20}$ J.S.T. Quah, Defying Institutional Failure: Learning from the Experiences of Anti-Corruption Agencies in Four Asian Countries. Presentation for the conference: Empowering Anti-Corruption Agencies: Defying Institutional Failure and Strengthening Preventive and Repressive Capacities, Lisboa, 14-16 May 2008, http://ancorage-net.org/content/documents/quah.pdf. Accessed 11 August 2012.

${ }^{21}$ J.R. Heilbrunn, Anti-Corruption Commissions Panacea, The World Bank Working Paper 2006, http://wbi.worldbank.org/wbi/Data/wbi/wbicms/files/drupal-acquia/wbi/Anti-Corruption\%20Commissions\%20by\%20John\%20Heilbrunn.pdf. Accessed 11 August 2012.

22 J.S.T. Quah, Combating Corruption in Singapore: What Can Be Learned?, "Journal of Contingencies and Crisis Management" 2001, Vol. 9, No. 1, p. 29-35.

${ }^{23}$ G. Makowski, Korupcja..., op.cit.; UNDP, Mainstreaming Anti-Corruption in Development, UNDP, New York 2008. 
foreign investors. The UN directly supported the creation of several ACAs in Africa. In the early nineties agencies were established in Tanzania (1991), Ghana (1993) and Malawi (1995). Also, other institutions such as the U.S. development agency USAID or its British equivalent, the Department for International Development (DFID) promoted the ACAs as one of the best methods of curbing corruption.

However, the greatest growth in the number of the ACAs around the world is associated with the formulation of a global anti-corruption policy framework. This happened mainly due to the efforts of the UN, OECD, World Bank, International Monetary Fund and other international institutions ${ }^{24}$. The breakthrough was particularly visible between 1995-1997, when the World Bank developed documents and recommendations requiring beneficiary states to implement national anti-corruption policies. At the end of the nineties, the European Union also joined the international front against corruption. The European Commission put strong pressure on the Central Eastern European countries aspiring to membership of the EU to develop special anti-corruption programs. Thus, in the case of Central and Eastern Europe, the majority of anti-corruption agencies were created during the accession process or shortly after joining the European Union ${ }^{25}$.

$* * *$

To sum up, the available data on anti-corruption agencies show that at least three phases in the historical development of these institutions can be distinguished. The first stage is the period from the end of World War II to the eighties of the twentieth century. Most of the ACAs at that time were created mainly to strengthen the structure of post-colonial states. During this time the main impetus for the creation of these bodies usually came from within the given country.

The second period of growth in popularity of the ACAs is associated with the end of the Cold War and the global wave of democratization of post-soviet authoritarian regimes. In the early nineties the ACAs were established under the influence and recommendations of the UN and Western development agencies.

The third and most dynamic stage of development is associated with even greater pressure from the international organizations which, in the second half of the nineties of the twentieth century, succeeded in formulating the framework for a global

${ }^{24}$ M. Bukovansky, Corruption Is Bad: Normative Dimensions of the Anti-corruption Movement, Australian National University, Working Paper 2002, http://ips.cap.anu.edu.au/ir/pubs/work_papers/02-5. pdf. Accessed 11 August 2012.

25 D. Dionisie, F. Checchi, Corruption and Anti-Corruption Agencies in Eastern Europe, ANCORAGE-NET Working Papers 2008, http://ancorage-net.org/content/documents/dionisie-checchi-corruption_in_ee.pdf. Accessed 11 August 2012. 
anti-corruption policy. The culmination of constructing this policy was the adoption in 2000 of the United Nations Convention Against Corruption which made the creation of anti-corruption agencies compulsory for all signatory countries. Thus, in the early twenty-first century, ACAs became the standard tool for counteracting corruption.

A further interesting conclusion we may draw from this short historical analysis is that the agencies created in the first period usually had a quite narrow specialization. The first ACAs were created in response to a concrete, specific situation in a given country. For example, the creation of special anti-corruption bodies in the U.S. almost always had their origin in a specific scandal. The first American anti-corruption unit was established in New York, to investigate the Tammany Hall scandal (1860s). It was similar in the case of Asian and Australian bodies. These early ACAs were focused on fighting administrative corruption, which was mainly related to their "police roots". Agencies in Singapore, Hong Kong and in New South Wales were established simply as special police units, and their first task was to fight corruption within the police.

As corruption has become globalized and its definition expanded, the ACAs have also broadened their scope. Nowadays they are expected to fight any kind of behavior classified by international conventions as corrupt. For almost all anti-corruption agencies established during the third wave the main purpose is fighting corruption, defined as a phenomenon far beyond the basic forms of crime occurring within administrative structures such as bribery or cronyism. Modern ACAs are supposed to deal with political corruption, corruption in the private sector or the banking sector (e.g. money laundering, which is often treated as a form of corruption) or in professional sport. The ACAs have also expanded their activities, as is expressed in broader competences and increased funding.

This evolution of anti-corruption agencies is related to the changes in the perception of corruption. At the end of the nineteenth century, corruption ceased to be considered as a problem of philosophical and moral nature; its practical consequences, and above all the fact that it causes dysfunctionality of state bodies, started to attract more attention from researchers, policymakers and public opinion. This "rationalization" of corruption paved the way for the creation of new very concrete anti-corruption measures ${ }^{26}$. An international anti-corruption campaign that was launched in the mid-nineties of the twentieth century broadened the definition of corruption, forming it in terms of a global social problem. This factor had a serious impact on the ACAs - the reasons why they had been established, what purposes

${ }_{26}$ P. Meagher, Anti-corruption Agencies: Rhetoric Versus Reality, "Journal of Policy Reform” 2005, Vol. 8, No. 1, p. 70. 
they served and what functions they performed. While the first ACAs were created by particular governments in order to solve the social problem of corruption as defined, managed and owned by them, those agencies established from the early nineties, were created mainly in response to the recommendations, expectations and pressure of the international community.

This process is somewhat similar to Anechiarico and Jacobs' account of "pursuit of absolute integrity" ${ }^{27}$. They analyzed anti-corruption policies in the U.S., looking more in-depth at the struggle against corruption in New York City. They identified four specific periods of anti-corruption development. The years 1870-1900 were the time of domination of the corrupt political machine, based on the spoils system and patronage. At that time there was no coherent anti-corruption policy. The period 1900-1933 they call the Progressive Era. At that time the risk of corruption in the United States could be greatly reduced by the development and implementation of ideas of apolitical administration and a professional, ethical civil service. The next period, between 1933 and 1970 is the time when a scientific view on the management of public administration became popular. This was the period of the birth of the New Public Management paradigm. It was also the time when belief that bureaucracies are not able to control the risk of corruption independently was cemented. It was discovered that they need external monitoring instruments - professional audit, control by investigation units specialized in analyzing irregularities in the public sector, by watchdog NGOs, etc. The fourth period, between the end of the 70's and 90's of the last century, Anechiarico and Jacobs label Panoptic. At that time the emphasis was put on strengthening control and the development of surveillance instruments to curb corruption. The case of New York in their opinion is extreme. The pursuit of absolute integrity in the city authorities made it a completely ungovernable structure. Anechiarico and Jacobs use the example of New York as an argument that excessive focus on reducing corruption does not necessarily go hand in hand with improving the quality of management. Also, the expectation that anti-corruption agencies can be a silver bullet to corruption is rooted in such a rationalistic view on this problem. However, Anechiarico and Jacobs' argument suggests that when such a silver bullet is used as dogma, it may easily make the ACAs lapse into irrationality.

27 F. Anechiarico, J.B. Jacobs, The Pursuit of Absolute Integrity. How Corruption Makes Government Ineffective, The University Press of Chicago, Chicago 1996. 


\section{Why do ACAs fail? The constructivist argument}

Available data allow us to formulate the opinion that despite anti-corruption agencies having become so popular, they are not very successful in performing their functions. The main reason why the ACAs are not able to fight corruption effectively lies in the nature of modern corruption, which is a diffused social problem.

As it was said earlier, in the case of corruption organizational ownership of this problem, and therefore the ability to define and determine the methods to counteract it, remains in the hands of those who initiated the process of constructing the social problem - international organizations, not national governments. When it comes to legitimizing the social problem of corruption in any given country, national governments have little to say. To see this, it is enough to analyze the legal definitions of corruption which we find in national legislations: first and foremost they must respond to the requirements of international anti-corruption conventions.

Lack of ownership of the social problem of corruption limits the freedom of choice of national governments as to what measures should be taken to curb corruption. Such a limitation is reflected especially by the UN Convention against Corruption, requiring signatory countries to adopt very concrete regulations (e.g. to penalize concrete behaviors in criminal codes or adopt special legislation to protect whistleblowers) and to create institutions prescribed by the convention, among which are anti-corruption agencies ${ }^{28}$.

Taking this into account, it should be no surprise that most anti-corruption agencies, especially in developing countries, were established solely as the fulfilment of the requirements imposed on them by international standards, without any deeper analysis of the problem of corruption in a given country and the country-specific solutions. This must have an impact on how the mission, goals and competences of the ACAs are defined and, as a result, how they function. One of the consequences is a sort of automatism in designing anti-corruption policies manifested in copying and applying the ACA models from other countries (usually from Hong Kong and Singapore - considered as the most successful).

Simple cloning ACAs from country to country often happens on the advice of international experts, who rarely have an in-depth knowledge of the political, social, cultural or economic determinants of the corruption and anti-corruption policies

${ }^{28}$ K. Hussmann, H. Hechler, H. Peñailill, Institutional Arrangements for Corruption Prevention: Considerations for the Implementation of the United Nations Convention against Corruption Article 6, U4 Anti-Corruption Resource Centre, Bergen 2009. 
in a given country. As a result their advice contributes to the creation of institutions that basically do not fit the local reality and in the end are ineffective - they lack political support and this results in poor legislation, resources and capabilities - and such institutions are not embedded in broader anti-corruption policies (if there are any), and also often suffer from low accountability. This is, as we will see later on, what happened in the case of most African and Asian ACAs, but also in Central and Eastern Europe.

\section{Conditions of ACA's success}

Successful ACAs should fulfil some basic requirements. In one of his articles based on a unique survey of high officials of anti-corruption agencies from fourteen countries de Sousa ${ }^{29}$, basing on his extensive survey of top ACAs officials from different countries identified several basic criteria the ACAs need to meet to be effective. Among them probably the most important are:

- a clearly defined mission and purpose; it should also be an element of a broad, horizontal, anti-corruption policy,

- broad political consensus,

- competences relevant to its mission purposes and resources,

- appropriate legislative framework,

- organizational culture promoting good leadership and high qualifications of its officials,

- good communication with other institutions dealing with corruption society and the international community.

Only by meeting these standards may the ACAs have a chance to be effective institutions. Unfortunately, the conclusion from de Sousa's analysis and other reports is that around the world there are few agencies which completely follow these principles.

Researchers analyzing anti-corruption agencies stress that the effectiveness of anti-corruption agencies is largely dependent on the motivations underlying the decisions to create them ${ }^{30}$. Lack of real political will to fight corruption and the simple desire to please the international community in this matter cannot be a solid basis for creating an effective anti-corruption agency. But what other motivations may governments (or at least most of them, especially after 2003) find to create and

\footnotetext{
29 L. de Sousa, Anti-corruption Agencies..., op.cit.

30 Ibidem; P. Meagher, Anti-Corruption Agencies, op.cit.; OECD: Specialized Anti-Corruption Institutions. Review of Models, OECD, Paris 2007.
} 
effectively use specialized anti-corruption agencies to fight a globalized, diffused social problem which they can hardly control? This is a problem which is difficult to define and even more challenging to operationalize for the purposes of a special anticorruption institution. This is a paradoxical situation and it might be expected that the authorities in such a situation would be driven by purely pragmatic motivation. Therefore, the ACAs' true purpose will not be limiting corruption, but (at best) only to control and keep it away from the political debate.

In most cases analyzed so far (as we will see in the next chapter), the ACAs are institutions prone to be used instrumentally in the political struggle or which are even themselves corrupt. The ACAs quickly become victims of politicians who, by creating an anti-corruption agency, present themselves as those who have fulfilled the highest international standards for combating corruption and have done their best to secure society form this terrible social problem. Such institutions definitely cannot play the role of an actor capable of making, or even initiating, any systemic change (e.g. reform of the party financing system) which is often necessary to limit corruption.

Diffusion of the social problem of corruption and the institutional ownership lying beyond national authorities, are two factors which make ACAs around the world (and especially those established since the mid-nineties on the growing wave of the global anti-corruption crusade), ineffective.

Of course there might be other explanations why the ACAs are dysfunctional. A general reluctance among politicians to establish anti-corruption agencies, or a tendency to create facade institutions, may be motivated by other reasons than just the nature of the problem of corruption. Dysfunctions may be due to the current political situation in a given country; they might be related to the character of the political system or the quality of political elites. An unclear mission or low ACA capacity may be due to the generally low organizational and management skills specific to the whole public sector in a given country. In such circumstances it will be unrealistic to expect that the ACA quality will be above average. Literature indicating more or less direct causes of the problems of anti-corruption agencies is discussed in the next chapter.

An interesting alternative argument might be derived from Bryane's (2004) analysis of the globalized diffusion of anticorruption policies. As an expert in the field of management studies, he stresses that if, and how effectively, anticorruption innovations are adapted by given societies and states heavily depends on how they are being transferred to the particular organizations. He proposes looking at this question through two perspectives: (1) organizational-led and (2) institutional-led diffusion of knowledge. Briefly, the first one is the situation when anticorruption policies are 
being copied or emulated by one organization or state to another ${ }^{31}$. Here, possible failures in transmission usually result from local, country or organizational specificity or inappropriate and incomplete information. As an example Bryane ${ }^{32}$ points to attempts of the World Bank, UN, or OECD or powerful development agencies (such as USAid or DFID) to spread anticorruption policies around the world. As was also mentioned earlier such efforts, especially when the creation of an ACA is at stake, are in most cases unsuccessful. Within the second model (institutional-led) it is assumed that knowledge exists somewhere "out there" (e.g. within social or policy networks) and factors like values, norms or culture characteristic to a given organization or country determine if knowledge (or policy) is transferred effectively or not. Transfer of an anticorruption policy will fail if an adapter is not prepared to operate according to an appropriate 'mental model', or is not able to learn and produce knowledge. Therefore, from such a perspective the ACA does not work effectively because the whole system (political, social, cultural, etc.) ignores values of transparency, accountability or good governance.

Here the existence of other factors is not denied, apart from the diffused nature of corruption, negatively affecting the ACAs. However, various factors may simply coincide with each other. By arguing that the character of the social problem of corruption is crucial to the ultimate success or failure of anti-corruption agencies another more horizontal (meso) perspective is brought. The hypothesis here is that diffusion of social corruption is a sort of pre-condition that generates other, more immediate problems for the ACAs, such as lack of resources, an inadequate legal basis or organizational problems.

\section{Common dysfunctions of ACAs. Some illustrations from available research}

As it was already said the main result of attempts of counteracting diffused social problem of corruption over which governments have no "organizational control" is that the ACAs are often established without political support and often become only façade institutions. An example here might be the Korean anti-corruption commission

${ }^{31}$ D. Dolowitz, D. Marsh, Learning from Abroad: The Role of Policy Transfer in Contemporary Policy Making, Governance 2000, Vol. 13, No. 1, p. 5-24.

${ }^{32}$ M. Bryane, The Globalization of Anticorruption Policies: The Diffusion of Best Practicies and the Role of Knowledge Management, in: D. Levi-Faur, E. Vigoda-Gadot (Ed.), International Public Policy and Management. Policy Learning Beyond Regional, Cultural, and Political Boudaries, Marcel Dekker, New York 2004. 
(KICAC), formed after a series of corruption scandals as proof of the government's determination to fight corruption, but at the same time deprived of investigation and prosecution competences ${ }^{33}$ (Quah, 2006).

This is also why anti-corruption agencies become victims of political struggle and are treated instrumentally by decision makers. This was the case of the Malaysian Anti-Corruption Central Office, which is almost fully dependent on the prime minister and the king, which makes it unreliable in the eyes of public opinion which sees this institution as a tool to fight political opposition. This is also the problem of the Polish Central Anti-corruption Bureau which is dependent solely on the prime minister's will and the current political composition of the parliament ${ }^{34}$. Very interesting insight on this can be also found in Robert Gregory's paper Political independence, operational impartiality, and the effectiveness of anti-corruption agencies ${ }^{35}$.

They often have unrealistic goals. Governments establishing ACAs (as a result of UNCAC ratification) expect that they will counteract every form of corruption (or even other crimes or threats), perform analytical activities and take care of information and public education ${ }^{36}$. There is a tendency to create multipurpose agencies or powerful law enforcement bodies with broad competences but few financial and human resources. As a result, the ACAs fail to achieve their goal, which lowers their social prestige and public confidence. This is the problem of the ACAs in Uganda and Zambia and other African agencies ${ }^{37}$.

A common shortcoming of the ACAs which are at the same time law enforcement bodies is an emphasis on the repressive functions, which often leads to the brutalization of the anti-corruption activities and even abuse of democratic standards and human rights. The Singapore CPIB and Polish CBA are often criticized for this reason ${ }^{38}$.

The decision to establish an anti-corruption agency should be a part of a broader anti-corruption policy; however, many agencies are created without such a plan or strategy and become the "fifth wheel of the coach". They do not fit the anti-corruption framework, if any exists, and from the very beginning are in conflict with

33 J.S.T. Quah, Curbing Asian Corruption: An Impossible Dream?, “Current History” 2006, Vol. 105, No. 690.

34 G. Makowski, Socjologiczna analiza..., op.cit.

35 Gregory, 2015.

36 See: K. Ernie, S. Yu-Chang, Y., Chilik, Sibling rivalry among anti-corruption agencies in Taiwan: Is redundancy doomed to fail?, Asian Education and Development Studies 2015, Vol. 4, No. 1, p. 101-124.

37 A. Doig, D. Watt, R. Williams, Measuring 'success' in five African Anti-Corruption Commissions Measuring 'success', Chr. Michelsen Institute, Bergen 2005.

38 P. Meagher, Anti-Corruption Agencies: A Review of Experience. University of Maryland: Center for Institutional Reform and the Informal Sector, 2004, p. 3; G. Makowski, Socjologiczna analiza..., op.cit. 
other institutions dealing with this problem. This was a problem of the Croatian agency (USKOK) ${ }^{39}$.

Even in the case of agencies which are widely believed to be successful, as in Hong Kong or New South Wales, it is difficult to adduce evidence that corruption was limited solely thanks to their work ${ }^{40}$. In these cases, the establishment of an agency was part of the wider anti-corruption strategy, which included reforms of the administration and implementation of new criminal law, etc. The ACAs also never operate in a vacuum; regardless of their degree of specialization, there are always other institutions, which do a similar job and are complementary to them ${ }^{41}$. Therefore, even if we can say that in Hong Kong and New South Wales the scale of corrupt incidents was reduced, the existing data will not prove that this resulted solely from actions taken by the ACA.

Meagher ${ }^{42}$ draws attention to yet another obstacle in attempts to evaluate the ACA effectiveness. In general, there is a very limited range of data which are usually made public by these kind of institutions. Therefore trying to answer the question whether the ACAs are a good or bad tool in fighting corruption, we immediately face very fundamental problems. Nonetheless answers these questions should be sought, bearing in mind the following points: 1) ACAs, as shown earlier, became a standard element of the global anti-corruption policy. 2) The international community and taxpayers in many countries have already made significant financial commitments to these institutions. 3) Identifying factors of success or failure in existing ACAs requires empirical analysis, especially taking into account the fact that conclusions drawn from the available data are not promising.

One of the first and best known studies of anti-corruption agencies is the Meagher report of 2004. He used the case study technique to analyze the ACAs operating in Argentina, Malaysia and Tanzania and several other agencies, including most famously the Hong Kong ICAC and Singapore's CPIB. The study strengthened the arguments in favor of the hypothesis that we cannot expect that ACAs will be the only, or even the major, factor which may reduce the scale of corruption. One of the most valuable observations we may draw from this report is that the overall effectiveness of the ACAs is very dependent on the moment and the circumstances in which they are created. Often, as Meagher noted, the authorities decide to establish an anti-corruption agency in response to a specific scandal or (as in the case of developed democratic countries), in response to the negative assessment of the previous

${ }^{39}$ D. Dionisie, F. Checchi, op.cit.

${ }^{40}$ D. Kaufmann, Revisiting Anti-Corruption Strategies: Tilt Towards Incentive-Driven Approaches, in: Corruption \& Integrity Improvement Initiatives in Developing Countries, UNDP, New York 1998.

${ }^{41}$ P. Meagher, Anti-Corruption Agencies, op.cit., p. 29.

42 Ibidem. 
cabinet and ruling party. An important impulse for establishing an anti-corruption agency is also pressure from international organizations. However, no matter what the decisive factor is, the ACA always has a chance to be successful if it is a part of a broader anti-corruption strategy, and if the decision to establish it results from political consensus ${ }^{43}$. Only in this way can an agency gain a strong position and long-term political support. Meagher gives examples of Singapore, Hong Kong, USA and New South Wales ACAs as success stories on the one hand, and on the other hand Tanzania and Botswana, where agencies were established simply in reaction to scandals and quickly lost their operational capability. The Tanzanian Prevention of Corruption Bureau (Taasisi Kuzuia Rushwa ya Tanzania), for instance, obtained very weak competences, low financial support and suffered a lack of public support (citizens simply did not even know that such an institution existed). These factors, combined with the lack of political consensus and a horizontal anti-corruption strategy, in the end led to the failure of the Tanzanian ACA.

A further important conclusion from Meagher's analysis concerns the scope of activities of the ACAs. In creating such an institution one needs to consider carefully what purposes it should serve. It is necessary to define agency functions in such a way that it will be able to counteract corruption and at the same time demonstrate its effectiveness to the public. This sounds easy, but when we take into account that nowadays corruption is very broadly defined, it is impossible for one institution to deal with the whole extent of this problem. Also, because of this broad definition it is difficult to narrow the ACA's scope and prove that it is fighting corruption really effectively. A thoughtless desire to copy the Hong Kong model (ICAC is the biggest and best funded, most existing ACAs have less than half of its budget) will end in failure. This is what happened in the case of ACAs established in Uganda, Thailand and the Philippines; a multi-purpose agency like the Hong Kong ICAC must have sufficient financial, human and technical resources, and these countries simply could not afford to create agencies like the Hong Kong ICAC. Thus, in deciding to establish an anti-corruption agency, it is reasonable to reject the ICAC model and clearly define the tasks and areas of activity of the institution according to the country-specific situation.

Yet another important issue discussed by Meagher is the accountability of the ACAs. Case studies show the ACAs have a tendency which is typical for all bureaucratic structures - to shut themselves into their own world and start living their own lives, becoming difficult to control. Anti-corruption agencies usually face

43 See: A. Mungiu-Pippidi, (Ed.), Contextual Choices in Fighting Corruption: Lesson Learned, 2011, http://www.oecd.org/countries/zambia/48912957.pdf Accessed 20 October 2015, p. 32, 52. 
serious problems of transparency, especially those agencies of a law enforcement character with broad investigation and prosecution competences. These problems of accountability were somewhat solved in only two cases - the Hong Kong ICAC and its counterpart in New South Wales (recently however the NSW ICAC changed this mechanism, and currently the Commission is supervised by the special Inspector of the Independent Commission Against Corruption and the NSW Parliamentary Committee on the ICAC). In both cases citizens are allowed to supervise these institutions directly, through special consultative bodies and councils who may order an audit over all activities of the ACAs. Without guarantees of accountability and transparency, due to the very political nature of corruption itself, the ACAs often become a tool in the hands of decision makers, seeking not to curb corruption but to use it in the political struggle.

Another interesting study of functioning of the central anti-corruption agencies in five African countries - Ghana, Malawi, Tanzania, Uganda and Zambia was done by Doig, Watt and Williams (2005); many findings from this study overlap with Meager's report. Maybe the most important conclusion from the analysis of African ACAs is that these institutions were created not because of an internal need to fight corruption, but only under strong pressure from international organizations, without proper diagnosis of the situation. African decision makers in fact had no motivation to establish effective institutions to limit corruption but only to satisfy foreign donors. The decision to establish the ACAs was not based on a coherent anti-corruption policy and genuine political will to deal with the problem. This, combined with unrealistic expectations (African ACAs were modelled again on the Hong Kong model) could not bring good results. Doig, Watt and Williams document here an important factor associated with the circumstances in which the ACAs are usually created - the impact of external claims-makers, demanding anti-corruption policy changes. African countries are only a few of the examples supporting the hypothesis that the lack of compatibility and synchronization between the objectives, opportunities, realities, motivations and expectations of governments and public opinion on the one hand, and the international organizations calling for establishment of anti-corruption agencies on the other hand, may lead to a permanent lack of effectiveness of the anti-corruption agencies.

Dionisi and Checchi ${ }^{44}$ draw similar conclusions. They analyzed the ACAs in Latvia, Lithuania, Slovenia, Bulgaria and Romania. The example of the Romanian Agency (Romania Anti-corruption Directorate - NAD) which, before this country joined the European Union in 2007, started investigating several high-ranking Romanian

\footnotetext{
${ }^{44}$ D. Dionisi, F. Checchi, op.cit.
} 
politicians, is particularly interesting. These cases were of course presented as successes of the government in curbing corruption. However, immediately after joining the EU the investigations were stopped and the cases did not reach court. A very similar situation happened in Bulgaria.

\section{Conclusion and one more hypothesis for further research on ACAs}

What lessons may be drawn from the rather negative experiences of existing anti-corruption agencies? Is there any chance to create a really effective anti-corruption agency in the context of constructivist explanation of the failures of the institution? Yes, of course, but some basic conditions have to be met.

As was mentioned before, there are several central anti-corruption agencies which are considered to be successful - the Hong Kong ICAC and its sister commission from New South Wales (Australia), the Singapore Corrupt Practices Investigation Bureau, the US Office of Government Ethics. These institutions (at least at some point) were successful due to the fact that the social problem of corruption - which they were established to fight against - was not diffused.

The ACAs in these countries were created in order to fight concrete, clearly defined forms of corruption, whose causes were identified in specific professional groups (problem populations) - the police or public administration ${ }^{45}$. Corruption was effectively personalized, and thus also instrumentalization of the problem and moving it to the very operational level, where anti-corruption agencies are active, was possible. Governments which decided to create these ACAs had full ownership of the problem and were not pressured by international actors. They were fully sovereign in their decisions. The Independent Commission Against Corruption in New South Wales was even created by the autonomous decision of one of the Australian states - the Australian federal government did not interfere. Thus, the organizational ownership of corruption remained in the hands of the authorities responsible for solving or controlling this social problem.

In such circumstances creating a special helping profession dealing with corruption was reasonable and could bring, and indeed brought, expected results. Therefore, in conclusion one more explanatory hypothesis which could be verified in further research on the ACAs.

45 J.S.T. Quah, Defying Institutional Failure..., op.cit.; T. Wing Lo, Corruption and Politics in Hong Kong and China, Open University Press, Buckingham 1993. 
Only when the social problem of corruption is not diffused, when it might be personalized, effectively instrumentalized and when ownership of the social problem of corruption belongs to the national authorities who are responsible for creating public policies and accountable for them, may anti-corruption agencies have a real chance to work effectively.

\section{Bibliography}

Anechiarico F., Jacobs J.B., The Pursuit of Absolute Integrity. How Corruption Makes Government Ineffective, The University Press of Chicago, Chicago 1996.

Benson R., Saguy A., Constructing Social Problems in an Age of Globalization: A French-American Comparison, "American Sociological Review" 2005, No. 70.

Best J., Constructionism in Context, in: J. Best (Ed.), Images of Issues: Typifying Contemporary Social Problems, New York 1995.

Bryane M., The Globalization of Anticorruption Policies: The Diffusion of Best Practicies and the Role of Knowledge Management, in: D. Levi-Faur.E. Vigoda-Gadot (Ed.), International Public Policy and Management. Policy Learning Beyond Regional, Cultural, and Political Boudaries, Marcel Dekker, New York 2004.

Bukovansky M., Corruption Is Bad: Normative Dimensions of the Anti-corruption Movement, Australian National University, Working Paper 2002, http://ips.cap.anu.edu.au/ir/pubs/work_ papers/02-5.pdf. Accessed 11 August 2012.

Charron N., Mapping and Measuring the Impact of Anti-Corruption Agencies: A New Dataset. Presentation prepared for the conference: New Public Management and the Quality of Government, Göteborg 2008, http://ancorage-net.org/content/documents/mapping-andmeasuring-the-impact-of-anti-corruption-agencies--a-new-dataset-for-18-countries.pdf. Accessed 11 August 2012.

Christie N., Dogodni wrogowie, in: M. Płatek, M. Fajst (Eds.), W kręgu kryminologii romantycznej, Liber, Warsaw 2004.

de Gruyter A., Slezak P., A Critique of Radical Constructivism, in: D.S. Philips (Ed.), Constructivism in Education, NSFSE, Chicago 2000.

de Sousa L., Anti-corruption Agencies: Between Empowerment and Irrelevance. Robert Schuman Centre for Advanced Studies Working Papers 2009, http://ancorage-net.org/content/documents/anti-corruption\%20agencies\%20between\%20empowerment\%20and\%20irrelevance. pdf. Accessed 11 August 2012.

de Sousa L., European Anti-Corruption Agencies: protecting the Community's Financial Interests, ANCORAGE-NET Working Papers 2006, http://ancorage-net.org/content/documents/williams,\%20robert\%20 (durham\%20university,\%20uk). pdf. Accessed 11 August 2012.

Dionisie D., Checchi F., Corruption and Anti-Corruption Agencies in Eastern Europe. ANCORAGE-NET Working Papers 2008, http://ancorage-net.org/content/documents/dionisiechecchi-corruption_in_ee.pdf. Accessed 11 August 2012. 
Doig A., Watt D., Williams R., Measuring 'Success' in Five African Anti-Corruption Commissions Measuring 'Success', Chr. Michelsen Institute, Bergen 2005.

Dolowitz D., Marsh D., Learning from Abroad: The Role of Policy Transfer in Contemporary Policy Making, "Governance" 2000, Vol. 13, No. 1.

Ernie K., Yu-Chang S., Chilik Y., Sibling Rivalry among Anti-corruption Agencies in Taiwan: Is Redundancy Doomed to Fail?, "Asian Education and Development Studies" 2015, Vol. 4, No. 1.

Fine G.A., Scandal, Social Conditions, and the Creation of Public Attention: Fatty Arbuckle and the "Problem of Hollywood", "Social Problems" 1997, Vol. 44, No. 3.

Gamson W.A., Constructing Social Protest, in: H. Johnston Hank, B. Klandermans (Eds.), Social Movements, Protest, and Contention, University of Minnesota Press, 1995.

Gamson W.A., Corteau D., Hoynes W., Sasson T., Media Images and the Social Construction of Reality, "Annual Review of Sociology" 1992, No. 18.

Girard R., Kozioł ofiarny, Wydawnictwo Łódzkie, Łódź 1991.

Gusfield J.R., Constructing the Ownership of Social Problems: Fun and Profit in the Welfare State, "Social Problems" 1989, Vol. 36, No. 5.

Heilbrunn J.R., Anti-Corruption Commissions Panacea, The World Bank Working Paper 2006, http://wbi.worldbank.org/wbi/Data/wbi/wbicms/files/drupal-acquia/wbi/AntiCorruption\%20Commissions\%20by\%20John\%20Heilbrunn.pdf. Accessed 11 August 2012.

Hussmann K., Hechler H., Peñailill H., Institutional Arrangements for Corruption Prevention: Considerations for the Implementation of the United Nations Convention against Corruption Article 6, U4 Anti-Corruption Resource Centre, Bergen 2009.

Jamrozik A., Nocella L., The Sociology of Social Problems. Theoretical Perspectives and Methods of Intervention, Cambridge University Press, Cambridge 1998.

Johnston M., Independent Anti-Corruption Commissions: Success Stories and Cautionary Tales, in: C. Fijnaut, L. Huberts (Eds.), Corruption, Integrity and Law Enforcement, Kluwer Law International, New York 2002.

Kaufmann D., Revisiting Anti-Corruption Strategies: Tilt Towards Incentive-Driven Approaches, in: Corruption \& Integrity Improvement Initiatives in Developing Countries, UNDP, New York 1998.

Krastev I., Stoyanov A., Prime Minister's Dilemma: Do Non-Corrupt Governments, "Working Paper Collegium Budapest", Budapest 2003, www.colbud.hu/honesty-trust/krastev/pub03. doc. Accessed 11 August 2012.

Krastev I., When "Should" Does Not Imply "Can" The Making of the Washington Consensus on Corruption, in: W. Lepenies (Ed.), Entangled Histories and Negotiated Universals: Centers and Peripheries in a Changing World, Campus Verlag, Frankfurt 2000.

Krastev I., The Strange (Re)Discovery of Corruption, in: R. Dahrendorf (Ed.), The Paradoxes of Unintended Consequences, CEU Press, Budapest 2000.

Krastev I., When "Should" Does Not Imply "Can" The Making of the Washington Consensus on Corruption, Fribourg Institute of Federalism, Fribourg 2003.

Kurczewski J., Czy możliwa jest socjologia korupcji?, in: J. Kurczewski, B. Łaciak (Eds.), Korupcja $w$ życiu społecznym, ISP, Warsaw 2000. 
Makowski G., Korupcja jako problem społeczny, Trio, Warsaw 2008.

Makowski G., Socjologiczna analiza funkcjonowania centralnych organów antykorupcyjnych. Międzynarodowa perspektywa i polskie doświadczenia, ISP, Warsaw 2010.

Meagher P., Anti-Corruption Agencies: A Review of Experience, University of Maryland: Center for Institutional Reform and the Informal Sector, 2004.

Meagher P., Anti-corruption Agencies: Rhetoric Versus Reality, “Journal of Policy Reform” 2005, Vol. 8, No. 1.

Meagher P., Anti-Corruption Agencies, OECD: Specialized Anti-Corruption Institutions. Review of Models, OECD, Paris 2007.

A. Mungiu-Pippidi (Ed.), Contextual Choices in Fighting Corruption: Lesson Learned, 2011, http://www.oecd.org/countries/zambia/48912957.pdf. Accessed 20 October 2015.

Pavarala V., Interpreting Corruption. Elite Perspectives in India, Sage Publications, New Delhi 1996.

Polzer T., Corruption: Deconstructing the World Bank Discourse, LSE Working Papers 2001, http://www $w^{2}$.lse.ac.uk/internationalDevelopment/pdf/WP18.pdf. Accessed 11 August 2012.

Quah J.S.T., Combating Corruption in Singapore: What Can Be Learned?, "Journal of Contingencies and Crisis Management" 2001, Vol., No. 1.

Quah J.S.T., Defying Institutional Failure: Learning from the Experiences of Anti-Corruption Agencies in Four Asian Countries, Presentation for the conference: Empowering AntiCorruption Agencies: Defying Institutional Failure and Strengthening Preventive and Repressive Capacities, Lisboa, 14-16 May 2008, http://ancorage-net.org/content/documents/quah.pdf. Accessed 11 August 2012.

Quah J.S.T., Curbing Asian Corruption: An Impossible Dream?, “Current History” 2006, Vol. 105, No. 690.

Quah J.S.T., Evaluating the Effectiveness of Anti-corruption Agencies in five Asian Countries: A Comparative Analysis, "Asian Education and Development Studies" 2015, Vol. 4, No. 1.

Robert G., Political Independence, Operational Impartiality, and the Effectiveness of Anti-corruption Agencies, "Asian Education and Development Studies" 2015, Vol. 4, No. 1.

Rubington E., Weinberg, M.S., The Study of Social Problems. Seven Perspectives (Sixth Edition), Oxford University Press New York 2003.

Schneider J.W., Social Problems Theory: The Constructionist View, "Annual Reviews" 1985, Vol. 11.

Sík A., The Bad, the Worse and the Worst: Guesstimating the Level of Corruption, in: A. Sajó, S. Kotkin (Eds.), Political Corruption in Transition: A Skeptic's Handbook, CEU Press New York 2002.

UNDP, Mainstreaming Anti-Corruption in Development, New York 2008.

Wing Lo T., Corruption and Politics in Hong Kong and China, Open University Press,

Buckingham 1993.

Woolgar S., Pawluch D., How Shall We Move Beyond Constructivism, "Social Problems" 1985, Vol. 33, No. 2. 
006_SzPP 3_2016.indb 78 